\title{
EFFect Of Head Teachers Support For Teachers Professional DEVELOPMENT ON INCLUSIVE EDUCATION IMPLEMENTATION
}

\author{
Douglas Isigi Shiwani $^{1)}$, Jeremiah Kalai ${ }^{2)}$, Winston Akala ${ }^{3)}$, Jane Gatumu ${ }^{4)}$ \\ ${ }^{1)}$ University of Nairobi, Kenya \\ E-mail: isiginon@gmail.com \\ ${ }^{2)}$ University of Nairobi, Kenya \\ E-mail: Jeremykala@gmail.com \\ ${ }^{3)}$ University of Nairobi, Kenya \\ E-mail: akalajumba@yahoo.com \\ ${ }^{4)}$ University of Nairobi, Kenya \\ E-mail: jgatumu@uonbi.ac.ke
}

\begin{abstract}
The study investigated the effect of head teachers' support for teachers' professional development on inclusive education implementation. Bartalanffy (1969) open systems advocates for head teachers to utilize management initiatives with partnerships to implement inclusive education. Descriptive survey was applied, and Chi-square tested the null hypothesis. Questionnaires were administered to 71 head teachers and 297 teachers, supplemented by document analysis. Interview was used on eight Quality Assurance Standards Officers (QASOs) and four Education Assessment Resource Centre Officers (EARCs). Quantitative data was coded and analyzed using descriptive statistics, and presented in frequency tables and bar graphs. Qualitative data was coded, transcribed and presented in narrative form. Both quantitative and qualitative data findings were discussed in juxtaposition with confirming or refuting the research evidence, and reinforcing the interpretation. The Chi-square results established that there was relationship between head teachers' support for teachers' professional development with inclusive education implementation. However, majority of head teachers and teachers lacked specialized skills in assessment of diverse learners, $77.5 \%$ and $80.5 \%$; behaviour management, $74.7 \%$ and $79.1 \%$; differentiated teaching, $80.3 \%$ and $81.1 \%$, derailing teachers' productivity and learners' performance. Therefore, it was recommended that head teachers in collaboration with multi-agencies facilitate teachers' inclusive education training in order to effectively implement inclusive education.
\end{abstract}

Keywords: Teachers' Professional Development; Implementation; Inclusive Education

\section{INTRODUCTION}

Research indicates that head teachers' training initiatives for teachers to handle learners with special needs enhance their outcomes (Hoppey \& McCleskey, 2013). Nevertheless, Horby (2010) attributes the challenges of implementing inclusive education to lack of teachers' specialized training initiatives. It is necessary that the personnel involved in the management of specialized teaching and learning resources have the requisite knowledge to use them because improper adapting of these resources or inefficient delivery of services can cause new and secondary health problems such as pressure sores, pain and deformities and also hinder learners with special needs access and participation in education (WHO,2008; Magnusson \& Ramstrand, 2009).
Mariga, McConkey and Myezwa (2014) study reveal that in Lesotho, Zanzibar and Tanzania, head teachers collaborate with NGOs such as Save the Children to fund and facilitate inservice and workshops for teachers' training in inclusive education, teaching pedagogies, managing and supporting learners. The training was facilitated by officials from multiagencies lasting over 18 months during school holidays. However, it was recommended that other training initiatives be identified to local school contexts because there was no guarantee for a set of initiatives to work in all contexts.

In Kenya, various public and private institutions of higher learning offer diploma and degree courses in broader educational and special education programmes. Most of these programmes are held during seminar, workshop, school holiday, and mainly adopt lecture method, which do not address learners with special needs and inclusive education 
context (Irungu, 2014). The Kenya Institute of Special Education (KISE) only trains 2000 teachers per year but does not make follow up on the practice in the schools (Irungu, 2014; Department for International Development, 2015). On the other hand, the Kenya Education Management Institute (KEMI) only offers broad educational management training programmes for school heads, which also does not address specific needs of learners with special needs within inclusive education (Irungu, 2014). Thus, it was imperative to examine how head teachers initiate for their teachers specialized training on specific skills to enable them teach and manage diverse learners.

The Department for International Development (2015) report, and National Special Needs Education Survey Report (Republic of Kenya, 2014b) revealed that learners with special needs are denied access in primary schools due to lack of resources and specialized teachers. In Nairobi City County out of 468,754 pupils who enrolled in primary schools only 1880 were special needs against the backdrop of 105,727 (Nairobi County Taskforce Education Report, 2015).The Handicap International (2013) report indicates that head teachers have great influence on teachers and community, and need to collaborate with stakeholders to institute initiatives for teachers' training to implement inclusive education. Therefore, there was need to address the gaps in head teachers' support for teachers' professional development on implementing inclusive education in schools in Nairobi City County.

\section{Statement to the problem}

Gathumbi, Ayot, Kimemia and Ondigi (2015) study on teachers and school administrators preparedness in handling learners with special needs in inclusive education in Kenya showed that $79 \%$ of respondents indicated that most teachers had not receive special education training with $88.6 \%$ attributing to lack of school administration and Ministry of Education support. Kenya Institute of Special Education [KISE] (2018) established that $13 \%$ of head teachers in special schools and $77 \%$ in integrated units did not have specialized training. According to Republic of Kenya (2014b) special need education survey, Nairobi City County had only $4.6 \%$ of special needs teachers (41 out of 1135 teachers), who are disproportionately distributed in special schools where they are given incentives. As a result, ccommunity members complained over lack of adequate specialized teachers in schools that refused to admit learners with special needs (Republic of Kenya, 2014b; Department for International Development, 2015). Therefore, it was imperative that this study interrogate head teachers' support for teachers' professional development to bridge the gaps in the implementing of inclusive education in schools.

\section{Review of related literature}

Aniscow (2003) argues that head teachers' initiatives for teachers professional development is key for implementation of inclusive education in schools. Research conducted by Hanin (2018) revealed that teachers specified the need for head teachers and administration professional development support, collaborative teaching with special education teachers in order to implement inclusive education. Consistently, Forlin (2004) as well as Gaad and Lavina (2007) studies showed that teachers were unwilling to undertake responsibility for inclusive education due to lack of head teachers' support for their professional development. Valeo (2008) study revealed that teachers acquire the requisite competencies to effectively implement inclusive education when training opportunities are initiated for them.

Merita and Tirana (2017) espouse that head teachers can provide training opportunities for teachers on inclusive education in collaboration with partners such as Save the Children. However, studies show that challenges facing head teachers in implementing inclusive education are attributed to inadequate professional knowledge, professional development and attitudes of teachers (Hornby, 2010). Nevertheless, research indicates that head teachers' specialized training initiatives for teachers enhance learners with special needs outcomes (Hoppey \& McCleskey, 2013). It was imperative to examine how head teachers as curriculum supervisors guide teachers to identifying training needs and facilitate their training to implement inclusive education in schools.

Westwood (2007) posits that in differentiated teaching, teachers change the lesson plan, class organization, delivery or methodology of teaching, use of teaching and learning materials or resources, and provision of alternative tasks. Hayes and Bulat (2017) differentiated and collaborative teaching entails adapting the curriculum to accommodate diverse learning and promoting individualized instruction. It does not mean developing a separate or alternative curriculum as this can limit learners' potential growth. However, it requires reviewing the national curriculum standards and determining how best to expose the learner to each standard and related performance using accommodations. Studies show that collaborative teaching using differentiated curriculum, behaviour counselling and management of learners result in improved performance and other learning outcomes (Paulsen, 2008; Forlin \& Rose, 2010).

Buhere and Ochieng (2013) postulate that pedagogical aspects of specialized competencies can be trained internally in school using resource or special teachers in collaborative teaching with regular teachers. However, Meenakshi, Anke \& Sip Jan Piji (2013) study on implementation of inclusive education in developing countries, argue that even though international organizations and NGOs have initiated some projects or programs, only 16 out of 140 countries had projects on inclusive education for learners with special needs in regular schools. On the whole, the effect of teacher training on implementation of inclusive education for learning outcomes for these learners has not been determined through research. It was therefore necessary to determine training areas that head teachers support teachers to implement inclusive education in schools through this research.

In Kenya, teacher training curriculum does not adequately address the needs of learners with special needs (Republic of Kenya, 2018a). Little time is allocated within initial teacher training for inclusive education. In addition, universities offer special education as elective unit (Mugambi, 2017). The Kenya Institute of Special Education (KISE) only trains 2000 
teachers per year (Department for International Development, 2015). This is inadequate to the increasing number of regular learners as well as learners with special needs. According to Kenya Special Needs Education Survey Report (Republic of Kenya, 2014b), only $17.9 \%$ of teachers utilize modifications to curriculum in their subjects, inasmuch as adapted curriculum is availed in schools. It was therefore plausible to examine head teachers' specialized training initiatives for teachers to fully implement inclusive education for diverse learners.

\section{METHODOLOGY}

A descriptive survey design was employed in this study. Creswell (2012) postulates that through this design a researcher is able to evaluate policy issues and programs, using questionnaires and interviews, and statistically analyze data to test research hypotheses. The target population had 4546 constituents from 203 public primary schools in Nairobi City County. The sample size was 514 respondents comprising of the nine Quality Assurance Standards Officers (QASOs) and four Education Assessment Resource Centre officers (EARCs), 102 head teachers and 400 teachers, selected using consensus and simple random, respectively.

Two sets of questionnaires were designed for head teachers and teachers, interview guides were used on QASOs and EARC officers to collect data; while, document analysis guides were used to cross-check the documents. The instruments return rates were $71(69.6 \%)$ and $297(74.3 \%)$ for head teachers and teachers' eight $(88.9 \%)$ and four $(100 \%)$ for QASO and EARC officers, respectively. Babbie (1989) in Best and Kahn (2006) suggest that a 50\% response rate is adequate, while $60 \%$ and $70 \%$ are good and very good, respectively.

Face validity was enhanced by consulting the supervisors and peers in the School of Education to review the tools on appearance, appropriateness of wording, content, and format of items. Pilot test was conducted on the instruments involving five percent of the sample size. Baker (1994) generally recommends between $10-20 \%$ of the sample size. However, Billingham, Whitehead and Julious (2013) argue that a formal sample size for pilot studies may not be necessary. Cronbach's alpha was employed to test the reliability of the instruments. The following reliability indexes were met: head teachers questionnaires, 0.876 and 0.926 ; teachers' questionnaires, 0.900 and 0.934; QASOs and EARCs interview guides, 1.00 and 1.000; document analysis guide, 0.945 and 0.960. Quantitative data was coded, analyzed using descriptive statistics, and presented in frequency tables and graphs. Qualitative data was coded, analyzed in themes, and presented in narrative form. Both quantitative and qualitative findings were interpreted and discussed in juxtaposition with confirming, reinforcing, and refuting research evidence as appropriate.

\section{RESULT AND DISCUSSION}

Head teachers' support for teachers' professional development for implementing inclusive education

Head teachers and teachers' responses on head teachers' support for teachers' professional development for implementation of inclusive education in schools are presented in Figure 1.

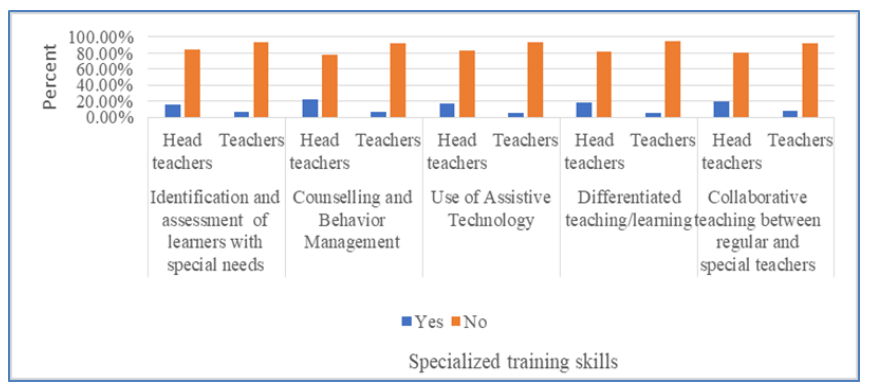

Figure 1. Responses on head teachers support for teachers' specialized training

Legend. $N=71 ; 297$ percentage $(\%)=$ percentage of head teachers and teachers responses on head teachers' support for teachers' specialized training in public primary schools in Nairobi City County.

Figure 1 indicates that majority of head teachers and teachers unanimously were in dire need for specialized skills in all the aspects. For example, identification and assessment of learners with special needs elicited $84.5 \%$ and $93.3 \%$; counselling and behaviour management, $77.5 \%$ and $92.6 \%$; use of assistive technology, $83.1 \%$ and $93.9 \%$; differentiated teaching and learning, $81.7 \%$ and $94.9 \%$; while, collaborative teaching between regular and special teachers solicited $80.3 \%$ and $92.3 \%$ from head teachers and teachers respectively. Very few respondents; presumably, in some special and integrated schools had received specialized training, posting low scores ranging between five per cent for differentiated teaching to $22 \%$ for counselling and behaviour management. These findings are corroborated with a study conducted by Odongo and Davidson (2016) that indicate that $84 \%$ of teachers (119 out of 142 teachers) were concerned about their training needs to meet the demands of learners with special needs in inclusive education, which they felt affect the performance of their peers. The training needs of teachers ought to be identified in the context of the school supported with clear records. QASO 3 regretted that:

Head teachers have not initiated any specialized training for teachers in schools. The very few special teachers in special/units rely on pre-service training. Teachers use their own experience to handle learners with special needs. Once a workshop was organized for EARC officers by Association for Physically Disable of Kenya (APDK) at Waithaka Special School, and they are required to sensitize schools.

The document analysis of the records on head teachers' support for teachers' professional development is shown in Table 1. 
Table 1. Records on teachers' professional development

\begin{tabular}{|c|c|c|c|c|c|c|}
\hline \multirow{3}{*}{$\begin{array}{l}\text { *Teachers' } \\
\text { professional } \\
\text { development }\end{array}$} & \multicolumn{6}{|c|}{ Available evidence of award/certificate } \\
\hline & Pre-service & & rvice & & inar & Total \\
\hline & $f$ & $f$ & $\%$ & $f$ & $\%$ & $\%$ \\
\hline $\begin{array}{l}\text { Identification } \\
\text { and assessment }\end{array}$ & 00 & 01 & 1.4 & 00 & 00 & 100 \\
\hline
\end{tabular}

of learners

$\begin{array}{lllllllll}\begin{array}{l}\text { Counselling and } \\ \text { Behaviour }\end{array} & 00 & 00 & 02 & 2.8 & 00 & 00 & 71 & 100\end{array}$

Behaviour

Management

$\begin{array}{lllllllll}\text { Differentiated } & 00 & 00 & 01 & 1.4 & 00 & 00 & 71 & 100\end{array}$
teaching

Note. $N=71 ;$ percentage $(\%)=$ percentage of head teachers responses on avait skills initiated for teachers in schools.

Document analysis in Table 1 indicate that there were no records on teachers' pre-service training and workshop on the various aspects of specialized skills. On in-service training, records show that 1.4 per cent of teachers were trained in identification and assessment of learners with special needs; counselling and behaviour management had 2.8 per cent; differentiated teaching had 1.4 per cent. These findings resonate with those of Gathumbi, Ayot, Kimemia and Ondigi (2015) study, which reveal that more than $79 \%$ of teachers had not received specialized training with $88.6 \%$ attributing to lack of school administration and Ministry of Education support.

Further analysis of the findings from Figure 1 revealed that there were a paltry $15.5 \%$ and 6.7 per cent of head teachers and teachers who contented that teachers had been trained on identification and assessment of diverse learners. These findings are adduced to KISE (2018) study that established that schools admission policies do not consider assessment of learners such that half of learners in integrated and a fifth in special schools in the country were not assessed prior to admission. In addition, it is corroborated with Juma and Malasi (2018) study whereby it was indicated that $72 \%$ of regular schools admitted learners with special needs without assessment.

On differentiated teaching, the findings in Figure 1 reveal that a meagre $18.3 \%$ and $5.1 \%$ head teachers and teachers felt that they had been trained in schools. Evidence refers that teachers have not been prepared on differentiated teaching/curriculum as $47 \%$ and $23 \%$ of teachers in integrated and special schools could not implement it for learners with special needs (KISE, 2018). It is indicated that due to lack of accommodations in terms of setting, instructions and extra time allocation, academic and examinations performance create unfavourable learning environment for these learners (Republic of Kenya, 2014b). Odongo and Davidson (2016) study accede that $83 \%$ of teachers were concerned about assessing the work of learners with special needs.

The findings in Figure 1 showed that only $19.7 \%$ and 7.7 per cent of head teachers and teachers felt that teachers could carry out collaborative teaching compared to the majority, $80.3 \%$ and $92.3 \%$ who strongly felt incompetent in implementing collaborative teaching. This demonstrates that majority of schools did not use collaborative teaching and learning method. It is evidenced in Buhere and Ochieng
(2013) study that head teachers did not support collaboration teaching between regular and special teachers.

Counselling and behaviour management is integral part of teaching and learning. Interestingly, the study showed that disappointing numbers of head teachers and teachers accounting for only $22.5 \%$ and 7.4 per cent had been trained; perhaps, in the notion of learning educational psychology in pre-service training. Contrastingly, disparaging numbers of head teachers and teachers representing $77.5 \%$ and $92.6 \%$ felt they lacked the competencies in this skill, an indication that head teachers had not initiated training in schools. In line with ithesse findings Gathumbi, Ayot, Kimemia and Ondigi (2015) study indicated that $69 \%$ of respondents felt that the school management did not have effective programmes such as peer support, tutoring and mentoring learners with special needs. Odongo and Davidson (2016) study reveal that $73 \%$ of teachers (103 out of 142 teachers) were concerned about management of diverse learners' behaviour in inclusive education, especially those with behavioural challenges and multiple impairments.

The response on teachers training on use of assistive technology from Figure 1 was such that $16.9 \%$ and 6.1 per cent of head teachers and teachers thought that teachers had acquired skill to use them. An overwhelming majority comprising of $83.1 \%$ and $93.1 \%$ were adamant that they lacked the competencies in using assistive technology. These findings imply that schools had done very little to acquire assistive devices and train teachers to use them in teaching. Buhere and Ochieng (2013) study reveal that regular teachers are indifferent towards use of assistive devices due to lack of specialized skills. However, Hsien, Brown and Bortoli (2009) as well as Hanin (2018) studies revealed that teachers with pre-service training in special education are more willing to teach and handle diverse learners in inclusive settings when they are provided with professional support services such as assistive devices. According to UNICEF (2015), the National Fund for the Disabled of Kenya provides AT and expertize services that head teachers can acquire for their schools. EARC 2 was disappointed to note:

Teachers are not facilitated or supported by the school administration to undergo specialized training in workshops, seminars or even within their schools. The way they handle special learners is not effective at all. There is lack of adequate trained teachers in all the areas except a few for hearing and visual impairments in few special schools/units.

\section{The effect of head teachers support for teachers' professional development on implementation of inclusive education}

The responses of head teachers and teachers' on the effect of head teachers' support for teachers' professional development on implementation of inclusive education are presented in Figure 2. 


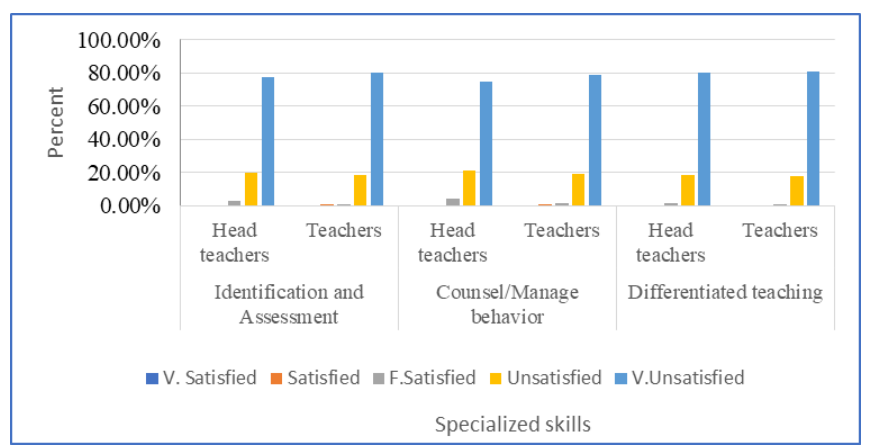

Figure 2. Responses on effect of head teachers support for teachers' specialized training on performance

Legend. $N=71 ; 297$ percentage $(\%)=$ percentage of head teachers and teachers responses on effect of head teachers' support for teachers' on performance.

Figure 2 indicates that majority of respondents expressed strong dissatisfaction on the effect of various areas of specialized skills that they were trained on to implement inclusive education in their schools. This is illustrated in the higher negative scores posted across the specialized teachers' training areas as indicated: identification and assessment of learners with special needs at $77.5 \%$ and $80.5 \%$; counselling and behaviour management $74.7 \%$ and $79.1 \%$; while, differentiated teaching had $80.3 \%$ and $81.1 \%$ of head teachers and teachers respectively. The implication is that teachers were not adequately trained in specialized skills to teach and manage diverse learners in schools; consequently, derailing both their productivity and learners performance. QASO 3 figured out:

Lack of specialized training for teachers, means they lack the necessary knowledge and skills to handle learners with special needs. I don't think that teachers teach them the same concepts they teach other learners because they lack the knowledge on how to differentiate their teaching. So, they teach them basic knowledge and pre-vocational learning, which I don't think can help them achieve their career goals.

Majority of head teachers and teachers representing $77.5 \%$ and $80.5 \%$ respectively, were very dissatisfied with the effect of identification and assessment of learners on both their work productivity and performance grades of learners. A very negligible number of respondents accounting for 2.8 per cent and one per cent were fairly satisfied with the effect of identification and assessment on their work productivity and learners performance. Contrastingly, Villa et al. (2003) study reveal that teachers trained in identification, assessment and placement of learners saw learners' enrolment increasing from $30 \%$ to $86 \%$ in regular schools. Therefore, from the foregoing discussion, it was prudent that teachers are not only trained in identification and assessment of learners but also were involved with multidisciplinary personnel within the school to assess and place learners so as to own and successfully implement inclusive education. According to Juma and Malasi (2018) study, 63\% of successful placement of learners in appropriate schools depends on a comprehensive multidisciplinary assessment of learners where teachers and other professionals are involved.
The findings on counselling and behaviour management of diverse learners from Figure 2 show that majority constituting $74.7 \%$ and $79.1 \%$ of head teachers and teachers strongly felt that the effect of counselling and behaviour management skills on their work and learners performance was very dissatisfactory. Disappointingly, only 4.2 per cent and 1.3 per cent of them were satisfied with the effect of counselling and behaviour management on performance. This contemplates that majority of the schools had not initiated teachers training on counselling and behaviour management for diverse learners; thus, teachers felt they lacked the competencies to mould, guide and mentor learners behaviour change, character and values towards academic performance. Causton and Theoharis (2014) posit that head teachers facilitate behaviour support for learners, by initiating programmes that integrate teaching and reinforcement of social and emotional skills in learning.

On differentiated teaching, majority $80.3 \%$ and $81.1 \%$ of head teachers and teachers in Figure 2 were strongly discontented with its effect on both their work and learners performance. It is contrasted to very low scores of head teachers and teachers at 1.4 per cent and one per cent who consented to its effect on performance. The implication is that majority of head teachers had not initiated specialized training for teachers on differentiated teaching. This hindered effective curriculum delivery, affecting both their work productivity and learners performance. EARC officer 2 clarified that:

Due to teachers' lack of specialized skills in teaching diverse learners, special learners are only taught prevocational skills to handle daily living activities not academic. Therefore, you do not expect these learners to sit for exams and perform like the other learners. They are already disadvantaged by the learning conditions in school.

The findings on differentiated teaching from Figure 2 are in tandem with Crispel and Kasperski (2019) that indicated that teachers have challenges in using differentiated teaching to cater for individual learners interests while at the same time maintain academic performance. Merita and Tirana (2017) study revealed that when teachers use differentiated teaching for all learners, they improve their academic achievement. In addition, Hayes and Bulat (2017) study found out that in USA and other developed countries, all learners achieve improved academic performance from differentiated teaching and learning used in inclusive settings. It was of essence that teachers were trained to acquire competencies not only in differentiated teaching but also the other specialized areas for effective curriculum delivery and managing of diverse learners geared towards satisfactory performance.

\section{Association between head teachers support for teachers professional}

development with implementation of inclusive education

The null hypothesis tested was:' there is no significant association between head teachers' support for teachers' professional development with implementation of inclusive education.' The independent variable was head teachers' support for teachers' professional development versus the dependent variable indicated in performance grades. The 
results are presented in chi-square statistical table. Tables 2 displays the statistical results of chi-square tests.

Table 2. Chi- square results *differentiated teaching/learning skills vis-à-vis performance

\begin{tabular}{lccc} 
& Value & $d f$ & Asymp.sig \\
\hline Pearson Chi-square & $2.119^{\mathrm{a}}$ & 2 & .347 \\
Likelihood Ratio & 2.099 & 2 & .350 \\
Linear-by-linear & .562 & 1 & .454 \\
Association & & & \\
N of valid cases & 71 & & \\
\hline
\end{tabular}

The chi-square results findings reveal that there was statistically significant association between head teachers' support teachers' professional development with implementation of inclusive education, in public primary schools.

\section{CONCLUSIONS}

Majority of head teachers and teachers had not undergone specialized training on key areas such as identification and assessment of learners with special needs. Thus, the lack of specialized competencies negatively affected teachers delivery of education services; consequently negating on diverse learners' learning outcomes.

Head teachers in conjunction with stakeholders should discuss training needs relevant to inclusive education, and facilitate teachers' specialized training. The training should be conducted on incremental modules by coordinated multiagencies.

\section{REFERENCES}

Aniscow, C.(2003).Inclusive education practices. London: Sage

Ainscow, M., Booth, T. \& Dyson, A. (2006). Inclusive and standards agenda:

negotiating policy pressures in England. International Journal of

Inclusive Education, 10(4), 295-308.

Baker, T.I. (1994). Doing social research. (2 ${ }^{\text {nd }}$ ed.). New York: McGraw-Hill

Bartalanffy, L.V. (1969). General system theory. New York: George Brazillier

Barton, P.E. (2003). Parsing the achievement gap: baselines for tracking progress. Washington DC: Princeton NJ.

Best, J. W., \& Kahn, J. V. (2006). Research in education (10th ed.). Upper Saddle River, NJ: Pearson Education, Inc.

Billingham, S., Whitehead, A.L. and Julious, S.A. (2013). An audit of sample Sizes for pilot and feasibility trials. United Kingdom Clinical Research Network Database, BMC Medical Research Methodology, 13 (104), 1-6.
Buhere, P., \& Ochieng, P. (2013). Usage of selected resources for inclusive education in mainstream primary schools: Issues and challenges from a Kenyan perspective. Problemsm of Management in the 21st Century, 8, 16-24

Causton, J., \& Theoharis, G. (2014). The principal's handbook for leading inclusive schools. Baltimore, MD: Paul H. Brookes Publishing Co.

Creswell, J.W. (2012). Educational research: planning, conducting and evaluating quantitative and qualitative research. ( $4^{\text {th }}$ ed.). London: Pearson Research.

Crispel, D. and Kasperski, R. (2019). The impact of teachers training in special education on the implementation of inclusive education in mainstreamed classrooms. Journal of Education, 112. Routledge Taylor and Francis Group DOI: $10.1080 / 13603116.2019 .1600590$

Cronbach, L.R. (1970). Essentials of psychological testing. (3rd ed.). New York: Harper \& Row.

Department for International Development (2015). Accessing inclusive education for children with disabilities in Kenya:global campaign for education. United Kingdom: DFID UK.

Forlin, C. (2004). Promoting inclusivity in Western Australian Schools. International Journal of Inclusive Education, 8(2), 185-202.

Gaad, E., \& Lavina, K. (2007). Primary mainstream teachers' attitudes towards inclusion of students with special educational needs in the private sector: a perspective from Dubai. International Journal of Special Education, 22(2), 95-109.

Gathumbi, A., Ayot, H., Kimemia, J. and Ondigi, S. (2015). Teachers and school administrators preparedness in handling students with special needs in Kenya. Journal of Education and Practice, vol.6(24), 129-138.

Handicap International (2013).Inclusive education in Kenya assessment report. Policy paper on inclusive education in Kibera \& Dandora. Nairobi.

Hayes, A.M. and Bulat, J. (2017). Disabilities inclusive education systems and policies guide for low and middle income countries. New York: RTI Press Publication.

Hoppey, D., \& McLeskey, J. (2013). A case study of principal leadership in an effective inclusive school. Journal of Special Education,45,245-256

Hornby, G. (2010). Supporting parents and families in the development of inclusive education in confronting obstacles to inclusion. London: Routledge.

Hsien, M.P, Brown, M., \& Bortoli, A. (2009). Teacher qualifications and attitudes toward inclusion. Australasian Journal of Special Education,33(1),

Irungu, J.M. (2014). Influence of head teacher leadership development on implementation of inclusive education in public primary schools in Kiambu 
County, Kenya [Unpublished $\quad \mathrm{PhD} \quad$ Thesis]. University of Nairobi.

Juma, S. and Malasi, F. (2018). The role of EARC in promoting inclusive education in Kenya.

International Journal of Science and Research. Vol.7(1), 885-889.

KISE (2018). The National Survey on Children with Disabilities and Special Needs. Nairobi.

Magnusson, L.\& Ramstrand, N.(2009). Prosthetist/orthotist educational experience and professional development in Pakistan. Disability and Rehabilitation: Assistive Technology. 4(6):385-92. 73.

Mariga, L., McConkey, R. \& Myezwa, H. (2014). Inclusive education in low-income countries: a resource book for teacher-educators, parents, trainers and community development workers. Cape Town: Atlas Alliance and Disability Innovations Africa.

Meenakshi, S., Anke de Boer, and Sip, J.P. (2013). Inclusive education in developing countries: a closer look at its implementation in the last 10 years. Umang, Jaipur Indian.Routeledge.TaylorandFrancisGroup. http://dx.doi.org/10.1080/00131911.2013.847061

Merita, P. and Tirana. (2017). Inclusive education for children with special education needs in Albania best practices. Tirane: Albania Italian Agency of Cooperation for Development.

Mugambi, M. (2017). Approaches to inclusive education and implications for curriculum theory and practice. International Journal of Humanities Social Sciences and Education, vol.4 (10), 92-106.

Nairobi City County. (2015). Taskforce education report. Nairobi.

Odongo, G. and Davidson, R. (2016). Examining the attitudes and concerns of the Kenyan teachers towards the inclusion of children with disabilities in the general education classroom: a mixed method study. International Journal of Special Education, 31(2), 1-30.

Pearson, K. (1948). Early statistical papers. Cambridge, England: University Press.

Republic of Kenya. (2018a). Sector policy for learners and trainees with disabilities. Nairobi: Government Printers.

Republic of Kenya. (2014b). National Special Needs Education Survey Report. Nairobi: Government Printers.

Saebones, A. M., Bieler, R. B., Baboo, N., Banham, L., Singal, N., Howgego, C., McClain- Nhlapo, C. V., Riis-Hansen, T. C., \& Dansie, G. A. (2015) Towards a disability inclusive education: Background paper for the Oslo Summit on Education for Development. Retrieved September12,2016,fromhttps://www.usaid.gov/sites/ default/files/documents/1865/Oslo_Ed_Summit_ DisabilityInclusive_Ed.pdf

UNICEF. (2015). Assistive technology for children with disabilities:creating opportunities for education, inclusion and participation. Geneva: WHO.

Valeo, A. (2008). Inclusive education support systems: teacher and administrator views.

International Journal of Special Education, 23 (2), 816.

Villa, R. A., P. M. Van Le Tac, S. Muc, N. T. M. Ryan, C. Weill Thuy, and J. S. Thousand. (2003). Inclusion in Vietnam: more than a decade of implementation. Research \& practice for persons with severe disabilities 28 (1): 23-32. Wehbi.

Westwood, P.(2007). Common sense methods of children with special needs: strategies for regular classroom. London: Routledge Flamer

World Health Organization. (2012, June 19 ). Assistive devices/technologies: what WHO is doing. Availablefromhttp://www.who.int/disabilities/technol ogy/ activities/en/\#.

World Health Organization (2008). Guidelines on the provision of manual wheelchairs in lessresourced settings. Geneva. 